\title{
OILS OF THE SEEDS OF SAMBUCUS NIGRA
}

E. I. Gigienova, A. U. Umarov, and A. L. Markman

Khimiya Prirodnykh Soedinenii, Vol. 5, No. 2, p. 117, 1969

Sambucus nigra (European elder) of the family Caprifoliaceae is distributed in the European part of the USSR, in the Caucasus, in Western Europe, and the Mediterranean region.

The oil of the seeds of this plant [1] have not previously been adequately studied [2]. We have investigated seeds collected in the Tashkent Tree Park (light brown transversely wrinkled seeds of tongue-1ike shape). The weight of 1000 seeds was $2.5 \mathrm{~g}$ and their dimensions $3 \times 1.5 \times 0.5 \mathrm{~mm}$. The core consisted of a liquid mass in a dense coat.

Table 1

\begin{tabular}{l|r|r|r}
\hline \multicolumn{1}{c|}{ Index } & \multicolumn{3}{c}{ Acids } \\
\cline { 2 - 4 } & mixture & saturated & solid \\
\hline Iodine No., \% & 184.37 & 3.98 & 4.05 \\
Thiocyanogen No., \% & 99.32 & $\overline{2}$ & $\overline{-}$ \\
Neutralization No., \% & 203.94 & 214.86 & 216.50 \\
Mean mol. wt. & 275.13 & 261.14 & 259.17
\end{tabular}

The amount of substances (oils) extractable by petroleum ether was $35.82 \%$ calculated on the absolute dry weight. The oil was pale yellow and odorless with $\mathrm{d}_{4}^{20} 0.9242$, viscosity $7.768^{\circ} \mathrm{E}$, saponification no. 189.23, acid no. 1.16 , Hehner no. 95.93, content of unsaponifiables $1.1 \%$ and of phosphatides $0.30 \%$.

The indices of the total fatty acids and of the saturated and solid acids isolated from them are given in Table 1 . The compositions of the fatty acids and their fractions, determined by gas-1iquid chromatography, are given in Table 2 . The oil of the European elder dries twice as fast as linseed oil.

Table 2

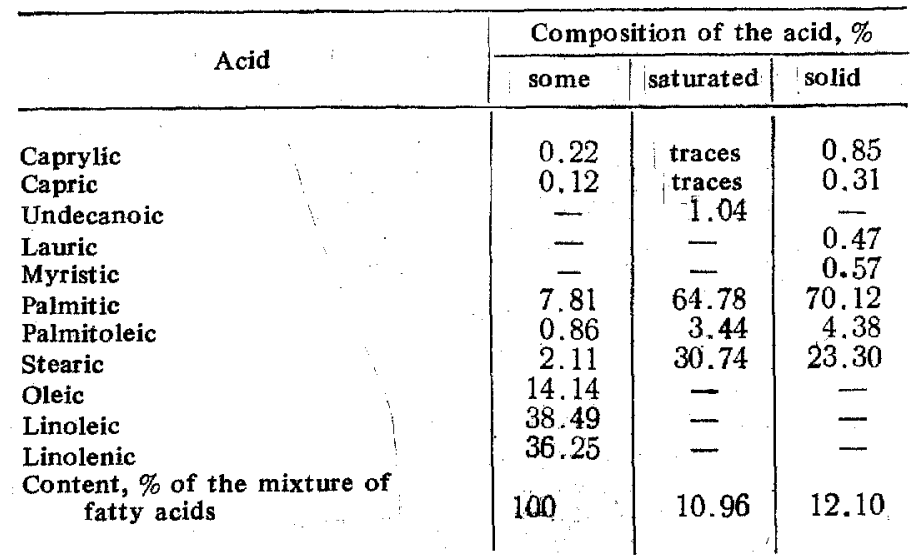

By a method, which we have modified, of chromatography on paper in the Alimova system [3] we found behenic and arachidic acids and an unidentified acid. The latter, like ricinoleic and dihydroxystearic acids travels with the front of the mobile solvent, is insoluble in petroleum ether, and gives a characteristic reaction for a keto alcohol.

\section{REFERENCES}

1. W. Z. Normann, Ang. Chem., 30, 16, 1917; Muth., Jahres der vereinig. angew. Botanik, 14, 36, 1917; Gisela, Nowak, and Zellner, Monatsh. , 42, 283, 301, 1921.

2. N. I. Sharapov, Oil-Bearing Plants and the Oil-Forming Process [in Russian], Moscow, p. 355, 1959.

3. E. K. Alimova, G. D. Bolgova, and O. I. Pustovoitova, Biokhim. , 25, 773, 1960. 